\title{
Soraya Isfandiari
}

BPKH Region XI, Regional Office of the Directorate General of Forestry and Environmental Planning, the Ministry of Environment and Forestry.

Email: soraya.isfandiari@mail.ugm.ac.id

Ambar Widaningrum

Departement of Public Policy and Management, Faculty of Social and Political Sciences, Universitas Gadjah Mada Email: ambarwid@ugm.ac.id

\section{Nunuk Dwi Retnandari}

Departement of Public Policy and Management, Faculty of Social and Political Sciences, Universitas Gadjah Mada Email: nunukdwiretnandari@ugm.ac.id

Submitted: 9 September 2020, Revised: 16 September 2020, Accepted: 17 September 2020

\section{Soraya Isfandiari}

Civil servant, was born in Bantul, Yogyakarta, Indonesia, 9 August 1972. Graduated from bachelor degree in the Faculty of Forestry, Gadjah Mada University, Indonesia in 1995 with specialization on forest management. She obtained her master degree on Double Degree Master Program: first, Master of Technique in Urban and Regional Planning from the Gadjah Mada University, Indonesia and second, Master of Arts in Urban Management and Development from the Institute for Housing and Urban Development Studies, Erasmus University Rotterdam and became the best student on graduation in 2006. Currently she worked as Head of Information Section on Environment and Forest Resources at BPKH

Region XI, Regional Office of the Directorate General of Forestry and Environmental Planning, the Ministry of Environment and Forestry.

\section{Ambar Widaningrum obtained her doctorate from Universitas Gadjah Mada in 2008, majoring in public administration. Lecturing at the Department of Public Policy and Management, Faculty of Social and Political Sciences, Universitas Gadjah Mada on the subject courses: monitoring and evaluation for policy program; gendering public policy. Her current research interests include social policy, public service reform, and gender issues. She is now serving as Chair of the Master Program in}

Policy \& Governance Review ISSN 2580-4820

Vol. 4, Issue 3, pp. 210-223

DOI: https://doi.org/10.30589/pgr. v4i3.350

\section{Land Issues in Forest Areas of Yogyakarta Special Region and The Dynamic of Decision Making Process}

\begin{abstract}
There is a forest land identified as Ab Gronden, located in Gunung Kidul Regency, Yogyakarta Special Region. Ab Gronden occupation has led to prolonged conflict over land until today. Environment and Forestry Service (EFS) of Yogyakarta Special Region has made a decision of "do nothing" from the policy set by central government to solve the problem. This study intends to examine factors underlying the decision of "do nothing". This type of research is a case study, that is a study on a policy in the context of real life and uses historical approach holistic single case study through the procedures of data collection and analysis systematically. The sources of data in this study consisted of both primary and secondary sources of data and were analyzed qualitatively. The results of this study found the following conclusion factors underlying of why decision of "do nothing" choosed by EFS is because of there is no policy agenda of forest land statue yet. EFS has experience a dilemma and conflict to make a decision relate to: a) the differences in the ab gronden perception among actors, b) multy level hierarchy of decision making, $c$ ) there is no initiation of dialogue between related actors. The Organizational Politics Model has not been able to work in decision making of government organizations that are grounded in legal provisions. The do nothing decision was made because the bargaining process between the actors was not running.
\end{abstract}

\section{Keywords:}

decision making; do nothing;Yogyakarta Special Region

\section{Introduction}

The problem of this research arises from the existence of community occupation in state forest areas and no resolution has been taken by the local government to resolve the issue. The local government policy that does not act in resolving land issues in forest areas is a choice of several alternative options available, and the policy will certainly have 
Public Policy and Administration, Universitas Gadjah Mada. Currently, she is conducting research on Governance for Handling the Covid-19 Pandemic: Crisis Management Policies in Indonesia.

\section{Nunuk Dwi Retnandari}

is a lecturer and researcher in the field of Public Administration. She obtained her Doctorate in the field of Economics and Development Studies, Faculty of Economics, Gadjah Mada University in 2005. She currently dedicates her experience and knowledge to teach in the Department of Management and Public Policy, Faculty of Social Sciences and Political Science, Universitas Gadjah Mada. She has research and writing interests in the areas of Local Economic Development, Economics for Public Policy, Development Management, Social Policy, and Development of Training for Government Planners an impact later on. Do nothing is a form of the policy choice "not to do" something by leaving the problem on one side is a possible condition as an alternative policy. Even though a policy of not doing anything is an option, a policy of delaying or neglecting land tenure in forest areas will lead to greater problems in the future (Kartodihardjo, 2017). The number of land problems in forest areas has increased with the stigma of the process of policy to resolve which requires a very long time (Awang, 2003; Ekawati et al., 2014).

Some research results in Indonesia show the phenomenon of "do nothing" by omitting. Omission done because there are no effective instruments from the Government to resolve cases in the field (Kartodihardjo, 2016); as the impact of unresolved conflicts (WALHI, 1999); as a form of continuity that has occurred in the field (Kartodihardjo, 2017); and as one model of conflict resolution in the hope that the conflict will be resolved by itself (Bappenas, 2009).

Government policy has actually been established at the national level, but many local governments have not implemented it due to various obstacles and causes. The government has discussed several efforts to overcome the problem of omitting land issues, including the Ministry of Agrarian Affairs and Spatial Planning / National Land Agency discussed a time limit for resolving land issues less than 5-10 years. Another policy was issued by the Central Government in an effort to resolve land issues in forest areas through Presidential Regulation No. 88/2017, which provides legal protection for the rights of communities who control land in forest areas. The policy as the country's priority in reducing land tenure problems in forest areas that have not yet been resolved.

Land occupation of state forest areas in Yogyakarta is one of problems that represent occupational issues that almost occur in all forest areas both in Indonesia and other countries. The specific thing about the occupation case in Gunung Kidul Regency is the special privileges owned by the Special Region of Yogyakarta. Of all the provinces in Indonesia, only the Special Region of Yogyakarta has special features in the land sector, so that land administration in the Yogyakarta Special Region has special policies that are not shared by other regions in Indonesia. This special policy in the field of land will certainly have an impact on the policy of solving land problems in it.

Land issues in the Yogyakarta Special Region have different characteristics from other regions in Indonesia. This is related to the condition that Yogyakarta is one of the provincies that gets special privileges from the Central Government, including with the privileges in land and spatial planning. Another peculiarity of this problem is that most people recognize that the land they use is state forest land and they are occupying consciously. Land occupation occurs with unlicensed 
use of forestry land for private, public and social facilities from 1965 to 2015 and is left without any effort to resolve the problem through a land problem resolution policy scheme established by the Central Government.

The land policy in DI Yogyakarta adheres to the dualism of the administrative system, namely the land policy in accordance with Law No. 5/1960 concerning Basic Rules for Agrarian Principles (UUPA), Law No. 41/1999 concerning Forestry and Law No. 13/2012 concerning Yogyakarta Specialties. The management of forest areas in Yogyakarta cannot be separated from the 3 land administration systems adopted in Yogyakarta. Many land conflicts and problems arise because of the dualism of land administration. Syafran (2016) said that land conflicts in iron sand mining policies in Kulon Progo Regency, Yogyakarta Special Province occured because of differences in the perceptions of actors about land status and policy risks as well as differences in the interests of actors over land values. The different perceptions among related actors regarding the status of the land are related to the problems of weakness in the land administration system in Yogyakarta Special Region that concerns the legal basis of land ownership, proof of legality of land ownership and the history of land ownership. The existence of problems in structural factors results in the strength of the perspectives of each actor in maintaining the status of land ownership based on their respective subjective opinions referring to different legal basis, proof of legality and ownership history.

\section{Research Question and Aims}

The do nothing policy is a unique policy because it is not documented, but the impact of the policy will cause problems to become more extensive over time. This phenomenon is an important side of this research to find out the factors that underlie the government conduct a policy of do nothing of land issues in the forest land in Gunung Kidul Regency. Land issues are conflicts of interest over land between several parties. The government has actually issued a number of policies in an effort to resolve land issues in this forest area, but the choice made by the regional government to carry out a do nothing policy by delay and omission has a side that needs to be studied in more depth on what makes the basis for making policy decisions. This research was conducted to present the do nothing decision by analyzing field phenomena and base on existing theories and literatures, whether related or whether it would bring up a review of pre-existing literature. Decision making by the regional government of Yogyakarta Special Region cannot be separated from the the land status and policy determined by the Central Government and it will make implications for the decision making process in solving land occupation problems in Gunung Kidul Regency, Yogyakarta Special Region.

The problem of this research arises from do nothing policy taken by the government in solving land issues in forest areas in the Special Region of Yogyakarta-The do nothing-policy is a policy choice made by the government with certain considerations which will certainly have an effect later on. As a reference in the case of land issues in forest areas in Java which are left without settlement has resulted in an increasing number of problems and complicates the resolution of cases (Forest Watch Indonesia, (2014); Bachriadi \& Wiradi, (2011); Ekawati et al., (2014) and (Kartodihardjo, 2017). In accordance with the specific case phenomena at the site level and the theoretical background that underlies this study, the main research question was focused on: what underlies the regional government in making do nothing policy in efforts to resolve land issues in forest areas in Gunung Kidul Regency.

This study also analyzes the dynamics of the decision making process among related actors. The background to decision making of do nothing needs to be known and analyzed to 
provide clarification of the background of the actual problems that occur and alternative policy choices. The objectives of the study are to (a) identify the dynamic process of decision making among actors to resolve the occupation in the state forest in the Gunung Kidul Regency in Yogyakarta Special Region and (b) to present the elements of do nothing policy regard to the land policy.

\section{Theoretical Review}

Public policy studies are actually studies of decision making. This study define the public policy as an explanation referring to the definition of public policy according to Thomas R. Dye: 'Public policy is whatever the government chooses to do or not to do". Dye, (1978) conveyed the background of "not to do" in the perspective of government organizations, how conditions in society that are not defined as a problem and no alternatives proposed will not be a policy issue so they do not get a place in the Public Policy Agenda. Under these conditions, the government will not take policy or do nothing so that the existing conditions will continue and there is no change at all. Dye emphasized that the most important thing in the decision making process is the power to determine what will be the policy issue, what is the problem is more important than determining what the solution will be.

This study tries to analyze the case of decision making "not to do" from the perspective of the Allison Model (Allison \& Zelikow, 1999) focus on the perspective of the Organizational Politics Model. Decision making of Alisson Model has 3 perspectives: Rational Actor Model, Organizational Behavior Model and Organizational Politics Model. The Organizational Politics Model is the spirit of the Allison Model.

This study will analize the policy issue and the process of decision making by the use of the Organizational Politics Model, how the process of bargaining among actors during the decision making process to make the compromise. Through the perspective of organization / bureaucratic politics, it is hoped that this research will have an element of novelty and be able to capture the "gap" that exists between theory and practice.

\section{Literature Review}

Decisions of do nothing are made in several forms through: neglect in policy-making (De Vries, 2010); non decision (Bachrach \& Baratz, 1962), inaction (McConnell \& 't Hart, 2019), omission (Ritov \& Baron, 1990), non decision making (Crenson, 1971); denial agenda (Elder \& Cobb, 1971).

The do nothing decision was initially stated by Bachrach and Baratz (1962) who defined "nondecision making," that is, 'the practice of limiting the scope of the actual decision making to safe issues by manipulating the dominant community values, myths and political institutions and procedures". This definition gets further development (revision) into " a decision that results in suppression or thwarting of a latent challenge to the values or interests of the decision maker". Then concluded that non-decision making power was "the less apparent butnonetheless extremely important face of power (Bachrach and Baratz, 1962). Rose \& Davies (2014) state "not to $d o$ " as "the exclusion of some alternatives from the agenda of collective choice because dominant values make them politically impossible for the moment".

Some literature that conducts a review of "not to do", do nothing or inaction decisions has a connection in providing an explanation of the factors that are the background of decision making. From some of these studies, it can be explained the background of the policy of "not to do" is that it can be done through omission (Bernstein, 2014), policy delays (Steunenberg, 2006); (Berger et al., 2015), avoidance (Moss \& Tubbs, 1996) and neglect (Kay, 2006).

Neglect is done as a choice of several alternatives which are predicted to make a problem worse if an action is taken (Kay, 2006). Delay is one of the typologies of policy 
implementation as conveyed by Goggins et al (1990) in Purwanto \& Sulistyastuti, (2012) who formulated a typology of policy implementation classified as deviations, delays, strategic delays and compliance. Steunenberg (2006) concludes that the delay arises in the decision making process between top-level actors which results in a deadlock. This deadlock situation will further lead to a delay in implementation. Deadlock issues emerge at the level of multi-level policy stakeholders and do not appear in the single actor coordination model. Differences in national (central) and regional policies will provide an opportunity for delay if there is a deadlock situation between policy makers.

The act of omission often arises in a prolonged conflict process. Sillars et al (1982) and Hocker and Wilmot (1991) in Moss \& Tubbs (1996) convey the omission activities as one of the behavioral typologies of conflict behavior namely avoidance, competitive tactics and collaborative techniques. Avoidance is one of the behaviors to avoid confrontation by delaying conflict cases encountered. The other literature describe by (McConnell \& 't Hart, (2019) that mention the main part of the paper presents five forms of policy inaction, followed by analysis of core inaction drivers at four policymaking loci: individuals (coping behaviour), public organisations (information pathologies), governments (agenda control and protection) and networks (non-coordination and lack of feasibility).

\section{Methods}

This study is a single case study (holisticsingle case study) where this research puts a case as the focus of research. The selected case is a case that has uniqueness and characteristics not found in other regions, so that it is feasible to be investigated as a case (Yin, 2009). This research is in accordance with Creswell (2005) is an indepth case study because it places the case as an object of research that needs to be investigated to explain the deepest value behind the case. The case of occupation in forest land in Gunung Kidul Regency is a unique case because the status of the land only exists in Yogyakarta Special Region. The uniqueness of this land status is in accordance with the special status of Yogyakarta Special Region, which is not given to other regions in Indonesia.

The research design focuses on the decisionmaking activities of omission over land tenure issues in forest areas. This research applies a case study, which aims to thoroughly understand the object of research, namely the policy of solving land problems in forest areas in Yogyakarta. Through case studies, this research is expected to be able to explain how the existence and why such cases could occur (Flyvberg, 2006; Yin, 2009).

The research is planned to be carried out with the object of land issues in the Ab Gronden in Gunung Kidul Regency. The region is a district in Yogyakarta Special Region with the widest area of forest and has a high complexity of land tenure issues in forest areas. Data collection is done through interviews with resource persons, field observations, and Focus Group Discussion for limited stakeholders. Data collection techniques rely on how the decision making process. Procrastination is a unique process because it is not documented but is a reflection of government policy to conduct a "do nothing" policy. The data needed in this study consists of primary data from interviewees and secondary data in the form of archives, documents, literature. Restrictions were made on land issues in the $A b$ Gronden that occurred during the period until - 2015.

This study focuses on decision making related to occupation in forest land. The focus of this study influences the methodology such as: a) interviewees are policy makers (key elements); b) resource persons are informants who have close links with the history of forest land administration (bureaucrats, academics, journalists, politicians 
and related individuals); c) resource persons are people who are familiar with the history of forest land administration. Interviews are conducted in a semi-structured interview approach, based on a list of related questions and are developed in accordance with information obtained at the time of the interview. This study uses historical research methods where in conducting qualitative data analysis, the research is carried out in depth, not proceeding in a linear thinking pattern. Data analysis was carried out from the beginning of the research and throughout the research process. Data from interviews, observations, editing, classification, reduction, to then be presented data, interpretation of data and conclusions of research data.

There are several obstacles encountered when collecting data in the field, related to : data sources are mostly historical documents starting from the 16th century where the availability of data is very limited and this study uses the basis of historical documents and interpretations based on the perspective of researchers on the availability of data.

\section{Results}

\section{Indonesian Land Policy}

Policies concerning land in Java could not be released from the forest, because at that time almost all of Java was in the form of forests which later became the beginning of the growth of kingdoms in Java. During the kingdom period, forest became a source of royal production and is the authority of the king. After the arrival of the Dutch, the VOC (Verenigde Oost Indische Compagnie) was established by the Dutch government in 1602 as a trading body that regulates the trading system and prevents competition among Dutch traders. Seeing the huge potential of forest wood (teak), the VOC began an agreement with the Kingdom of Mataram (1677) to establish a boat-building in Rembang. At this time the system of forest land ownership had not changed, the forest was still under the authority of the king.

The change in land policy occurred when the Dutch Government handed over the government to the British Government in 1811. During the British administration, Thomas Stamford Raffles (1811-1816) established a land tax policy, because according to him all land was the eigendom of the Gupernemen (Gouvernment). In Raffles' perspective, all land belongs to the British Government so that every citizen who uses and utilizes land must pay land / land tax to the Government (landrente). During the Raffles period, a political contract took place on August 1, 1812 between Raffles and Sultan Hamengkubuwono II (Yogyakarta Sultanate). This agreement confirmed that the British government held the right to control all plants (teak) while the land remains the property of the kings. In the agreement, the British government left a different status on forest land in the royal land area (vorstenlanden). This difference only existed in the vorstenlanden region (Yogyakarta and Surakarta) while for other regions, power over forests (plants and land underneath) became the authority of the colonial government.

In 1816, the Dutch Government hand over again government from British Government. In addition to forest management, the colonial government also developed plantation policies through the cultuurstelsel system during the Governor General van den Bosch (1830-1870). During this time there was an ecological change from forests and rice fields to plantations. Plantation development was carried out by the private sector with a rental system. At the insistence of investors who wanted expansion of the cultivated land, the colonial government established the Agrarian Law (Agrarische Wet) through Staatblad 1870/55. Through this law land ownership in Java was revoked and for land where there was no proof of ownership it could be submitted to a private company. This 
policy was continued with the enactment of the Forest Management Law (Staatblad 1874/110 corroborated with Staatblad 1927/221). Both of these legal provisions affirm the state's rights to forest and non-forest land. The state (the Dutch government) has the right to exploit, collect taxes and the right to lease state land to the private sector. The management of forest land is then carried out by Boschwezen (Forest Service). The Agrarian Law and The Forest Management Law are excluded on royal lands (vorstenlanden) in accordance with the Treaty between the British and Dutch Governments (1812) (Poerwonegoro, 1953).

The urge to reorganize the land is also directed to the vorstenlanden region. The land arrangement in Yogyakarta Sultanate was carried out with the stipulation of Sultanate (Sultanate Rijkblad 1918/16). In this provision, it was stated that all land that did not have ownership domains, was the authority of the Sultan of Yogyakarta. This forest land included the Sultan's authority, and forest wood was managed by Boschwezen with the Sultan's approval. The arrangement of forest land was carried out by Boschwezen by drawing, measuring in the field and mapping. After there was a definitive measure, forest management methods would be carried out starting from planting, to harvesting wood products.

This political contract continued with the signing of an agreement between Sultan Hamengkubuwono IX with the Dutch Government on March 18, 1940 which included mentioning that the forest land owned by the Sultan, and in the form of forest management was carried out by the Forestry Service after negotiating with the Sultan.

After independence, the Government drafted an agrarian law as a substitute for colonialera legal products. The Agrarian Law (UUPA) was passed on September 24, 1960 as the Basic Agrarian Regulation, which became known as the Basic Agrarian Law or Law 1960/5 (State Gazette 1960/104). Since September 24, 1960 the colonial agrarian law was no longer valid and had been replaced by the national law. In addition to the Basic Agrarian Law, the Government enacted the Basic Forestry Law through Law 1967/5 (in conjunction with Law 1999/41). In the Forestry Law regulates state authority over the land of forest areas which is determined to be state land.

Land administration was also championed by the Regional Government of Yogyakarta, referring to the history of Yogyakarta specialties. The history of the specialties of Yogyakarta which recognized by the Government through the stipulation of Law 2012/13. With the promulgation of the Yogyakarta Privileges Law, Yogyakarta Special Region has specificity in regional head elections, local government institutions, culture, land and spatial planning. Privileges in field of land, set out in the land policy: "lands that do not have ownership rights to become Sultan's lands"(Poerwokoesoemo, 1985).

\section{Forest Land Occupation}

Specific problems were encountered with the $A b$ Gronden status that existed in the village map in Gunung Kidul since forest arrangement in the Gunung Kidul afdeling in 1920-1932. The $A b$ Gronden status has a special term that does not yet exist in the information on the forest management map. Based on historical documents defined that Ab Gronden is initially of Afgescheven djatibosch Gronden.

During Dutch Government, ab gronden was managed by Boschwezen. After the forest arrangement in Gunungkidul was completed in 1932, ab gronden was excluded from forest management because the areas were too small and scattered so were not effective when managed by forest management system. Then the status of $A b$ Gronden had not been followed up, but the land was managed by the Village as stipulated in Sultanate Rijkblad 1918/16. Recording Management by the village continued until 1998, when the Regional Office of the Ministry of Forestry of Yogyakarta 
Special Province conducted an inventory of forest land in the Yogyakarta Special Province. From the results of the inventory, the Regional Office of the Ministry of Forestry of the Special Province of Yogyakarta submitted a recommendation to establish $A b$ Gronden as a forest area to the Governor of Yogyakarta. The Governor of Yogyakarta (Sultan Hamengkubuwono IX) gave a recommendation for the inauguration of $A b$ Gronden through letter No. $522 / 0211$ dated January 30, 1999. Based on the recommendation from the Governor of Yogyakarta, the Minister of Forestry issued a Decree on the Appointment of Ab Forest as a State Forest area in accordance with letter Number 197 / Kpts -II / 2000. After obtaining approval from the Minister of Forestry, the steps that must be carried out were the delineation of boundaries, minutes of boundary management and determination by the Minister of Forestry. The end of the inauguration process took the form of the determination of state forest areas definitively by the Minister of Environment and Forestry.

Related to the $A b$ Gronden status, after being removed from the management of teak forests, it turns out that the surrounding community still considers that $A b$ Gronden is a forest land. However, because the land was not managed again by Boschwezen, the community used it for community forests, agriculture, and the yard. Until now the community still has a perspective related to the $A b$ Gronden status, so that when they use $A b$ Gronden, the community is aware of returning the land if at any time the government or the Sultan asks for the land back. The next problem that occurs is that there has been a shift in the perspective of utilization from the original for community forests shifted to agriculture and yard (tree crops) and the use now is construction of buildings for both private and public facilities. At present almost all Ab Gronden areas have been divided into uses, either through a permit scheme from the Government or without permission as table attached.

Table 1.

The Usage of $A b$ Gronden in Gunung Kidul

Regency, Yogyakarta Special Province

Usage

Community Plantation

Forest (Hutan Tanaman Rakyat)

Village Forest (Hutan

Desa)

Forest Managed by

DLHK

Other usage by

Community (ocupation)

- Public facilities 58 Without permission

- Agriculture 605 Without permission

- Housing and privat 467 Without permission building

Source: Departement of Environment and Forestry, Yogyakarta (2018).

\section{Discussion}

\section{Central Government Decision : Bargaining vs Provision of Law}

In the issue of Land in Forest Areas, the Ministry of Environment and Forestry as a central organization is very much adhering to the policy norms set by the Central Government. Presidential Regulation itself is a legislation that has a high position, under the position of Government Regulation, which the Ministry of Environment and Forestry has the duty to implement in accordance with the provisions in it. The mandate of Presidential Regulation 2017/88 concerning Settlement of Land Issues in Forest Areas has been firm, for areas with forest area less than 30\% (Java island) with a resettlement mechanism, Exchange of Forest Areas or with Social Forestry.

The Organizational Politics Model as a model that offers a political bargaining / compromise (Allison \& Zelikow, 1999) and is actually not known in the bureaucracy that refers to the provisions of the law (Rostow \& Friedmann, 1972). Exemption schemes or special policies do not have provisions in the Presidential Regulation, so according to the normative, the Ministry of Environment and Forestry does not conduct a 
political compromise over the land issue in $\mathrm{Ab}$ Gronden in Yogyakarta Special Region.

Related to the dualism perspectives of forest land statue is a new thing and has never happened in the Ministry of Environment and Forestry, so that it requires an in-depth study in order to make government policy by an Integrated Team that involving academics. The results of the study are then used as input and policy advice to the Minister of Environment and Forestry. It is necessary to study alternative solutions, which allow for a policy which is a "bargaining" between the Central Government and the Special Region of Yogyakarta. It is realized that without compromise between government organizations, the problems that occur will not be solved because of differences in perspective. The process arises at the level of multi-level-policy stakeholders (Steunenberg, 2006) and because of there is no instruments from government to resolve cases in the field (Kartodihardjo, 2017)

\section{Local Government: No Dialogue Initiated}

In the case of occupation that has been happening for a long time, discussions between the local government starting from the Village Government and related agencies have not been carried out on an ongoing basis. Discussions are still being carried out inclusively within the EFS, Provincial Government - Village Government (carried out starting in 2011 followed by an inventory of occupied land and lands that have been provided by the community as replacement land in 2013-2015).

Problems encountered by the EFS Office in the effort to solve problems in the ab gronden, besides due to problems at the policy level were found to be from cross-sector intern of local governmnet. The communication barrier after being confirmed was also related to the position of the EFS Office which stood on two legs (the Ministry of Environment and Forestry and the Local Government of Yogyakarta Special Region).
The EFS Service has so far been "confused" in taking a stand. In discussing the policy on solving the ab gronden issue, the EFS Office has so far coordinated with the Technical Implementation Unit of the Ministry of Environment and Forestry. And the policies recommended through the Central agency are: resettlement or Forest Area Exchange. The two mechanisms are very difficult for the Local Government to take because they are related to the status of the forest area (state) in Yogyakarta Special Province (Boyle \& Heimans, 2014; Kay, 2006)). The difficulty triggered the Head of the EFS Service find dilemma to make a policy choice to do nothing.

This ab gronden issue is that there is no dialogue initiated by the local organization (EFS Service) with the other stakeholder. In the Organizational Politics Model, the true unit of analysis is the government's decision as a result of the political process/resultant political bargaining (the best decision of the relevant actors). Decisions as a result of compromise on problems, conflicts, differences in perception and politics are not the same (Allison \& Zelikow, 1999). The decision was a decision taken by the Head of the EFS Office is in term of do nothing policy, in which in terms of the organization as a decisive actor in the forestry sector policy of the Local Government and also a vertical agency actor from the Ministry of Environment and Forestry (Moss and Tobbs, 1996; Steunenberg, 2006, Berger, 2015).

\section{Policy Agenda}

Occupational issues in the forest area in Gunung Kidul Regency, Special Region of Yogyakarta cannot be separated from the national land administration in force in the Special Region of Yogyakarta, namely Agrarian Law 1960/5; Basic Forestry Law 1967/5 jo No. 1999/41 and Yogyakarta Privileges Law 2012/13. Problems related to Ab Gronden's status are issues that must be included in the Regional Government's policy agenda, due to differences in perspectives 
related to Ab Gronden's status. This difference can be observed as follows:

- Central Government Perspective :

Central Government (Minister of Environment and Forestry) has a perspective of Ab Gronden based on The Minister of Forestry's Letter Number 197 / Kpts-II / 2000, stated that Ab Gronden is included in the State Forest Zone ${ }^{1}$.

- Local Government Perspective :

In accordance with Tractaat 1 August 1812, Rijkbblad Sultanate No. 1918/16 and Hamengkubuwono IX's political contract with Dutch Government on March 18, 1940 and Yogyakarta Privileges Law 2012/13, stated that the land that didnot yet have ownership rights is belong to the Sultanate of Yogyakarta (Yogyakarta Palace). Asserting that the ownership of $A b$ Gronden was in the Sultanate of Yogyakarta, and the Sultan had never relinquished the rights of $A b$ Gronden to other parties.

The different perspectives on the Ab Gronden status have caused problem within the Yogyakarta Govenrment (Fernando, 2010; Syafran, 2016). The Environment and Forestry Service (EFS) has the duty and function as regional government organization and at the same time carries out central policy policies related to the environment and forestry. The policy of the EFS which holds the Minister of Forestry's decree regarding the status of state forest areas in Yogyakarta Special Region is seen as a matter that does not take sides with the provisions of Yogyakarta's specialties. The policy position of the EFS is a dilemma, where the Head of Office has a difficult position between two

\footnotetext{
${ }^{2)}$ Land in the territory of the Republic of Indonesia is divided into private and state land (for which land administration is carried out by the Ministry of Agrarian Affairs) and state forest land (where land administration is carried out by the Ministry of Environment and Forestry). The land administration of privat and state kland based on the Agrarian Law No. 5/1906 and state forest land based on Forestry Law No. 5/1967 jo No. 41/1999.
}

policies that have the same legal position and the Head of Office does not have the authority to make policies in it (Cohen et al., 2007). This condition give an result the Head of the EFS in choosing a do nothing policy is the existence of multilevel decision making on the policies of the central government and regional governments. This multi-level hierarchy of decision making resulted in a deadlock situation for the Head of the Office of EFS (Steunenberg, 2006).

With the existence of occupations in $A b$ Gronden, the EFS carries out a policy to settle occupational problems in $A b$ Gronden through the Exchange of Forest Area Exchange scheme. This scheme is a policy stated in Presidential Regulation Number 2017/88. There is no other policy that can be taken apart, except through the Forest Area Exchange and Resettlement mechanism but this swap policy was apparently not possible in Yogyakarta Special Region because of differences in perspective related to Ab Gronden's status. Problems related to the $A b$ Gronden status turned out to be the real core of the problem, and the actual settlement occupation was only an excess. If the status issue can be resolved, the follow-up to the Ab Gronden occupation settlement can be completed.

In conditions of dilemma and conflict, the Head of the of EFS select a do nothing policy, which is to allow problems and to postpone policies determined by the Central Government through the Exchange of Forest Areas (Presidential Regulation 2017/88) (Cohen, et al, 2007; Moss and Tubbs, 1996; Kay, 2006). As Dye, (1978)said this do nothing policy was carried out because there was no policy agenda related to $A b$ Gronden's status. The issue is the problem of occupation in Ab Gronden, do not have an understanding in the perspective among regional apparatus organizations inYogyakarta. The understanding of this perspective is related to the existence of land policy material in Indonesia which contains material "dualism of land policy" which is related to the forest policy and the privilege policy of Yogyakarta. 


\section{Governmental Politics Model (Allison Model)}

The governmental politics model is a model that describes the bargaining process to obtain the final decision of the relevant actors. The final decision is reached as a political resultant, a compromise over the problem because of differences in perspective and conflict. Decision making is carried out jointly by various actors, groups and interested parties after going through a long and complex process.

From the explanation related to the status of state forest area, especially the ab gronden, information was obtained that there were differences in perspective on the status of $a b$ gronden in the internal of the Yogyakarta Special Region government, and between the Yogyakarta Special Region and the Ministry of Environment and Forestry. This perspective difference has resulted in internal conflicts among regional apparatus organizations in the Yogyakarta Special Province in a conflict that is not open.

In the Governmental Politics Model, researchers are required to be able to find conflicts that arise between bureaucratic actors and how compromises and bargaining positions can be made between actors. Conflicts that arise in efforts to resolve land issues in forest areas are in fact a hidden conflict, and not open to be discussed. This occupational problem only appears at the regional level, in the forestry sector.

In taking data and information to respondents, information was obtained that each resource person had a "separate bargaining decision model", so that the decision as a process of political consequence between related actors: between actors from the Ministry of Environment and Forestry and EFS of Yogyakarta Special Province, did not yet exist. Differences in perspective do not yet have a common ground because there has never been an initiation or synchronization effort over differences in perspectives and existing conflicts. Each has an opinion on their respective duties and authorities and the resolution authority.

The Organizational Politics Model in this research is a necessity where there is a deadlock between the Local Government and the Central Government. This deadlock results in a do nothing decision, in which the local government does not do anything, there is no compromise over the problems caused by problem of differences in perception that are not resolved. The Head of the EFS Office actually did not decide anything, and this decision has taken place since the previous Head of EFS Office has been followed by his successor to the present. There are no proposals or dialogues conducted by other institutions among organizations in Local Government of Yogyakarta Special Province.

In the issue of $a b$ gronden occupation, in connection with the discussion of occupation in ab gronden so far carried out by the EFS Service Central Government, the Head of the EFS Service submits a request for settlement to the Ministry of Environment and Forestry in completing the occupation through the Exchange of Forest Area Exchange mechanism. The EFS Office has never had a dialogue with the Local Government of Yogyakarta Special Region in the realm of discussion of land and occupation issues that have occurred until 2015. The EFS Office has not fully held the perspective of the status of the $a b$ gronden as Sultan Grond (Sultan's Land). In forest administration and management, the EFS Office adheres to the Decree of the Minister of Forestry concerning the Appointment of ab gronden as Production Forest Areas.

Unopening the discussion regarding the status of the ab gronden and the efforts to resolve the problems that occur in it will have an impact on the resolution policy. Deadlock due to the absence of a compromise room occurs because the EFS Office does not open up opportunities for compromise on the perspective of the Local Government of Yogyakarta Special Province 
which adheres to the status of the ab gronden. With the choice of making a do nothing decision and letting go of the problems that occur, the EFS Office actually takes the best decision, because it is related to the conflict of policies that have a higher level of legislation than the policy level of the Office Head. From the authority of the Head of Office the choice is the best alternative, but from the perspective of the State, the decision does not resolve community problems over the status of the land they use. And the problem of $a b$ gronden occupation will not be resolved without a compromise between the politic-bureaucrats concerned.

The perspectives of the bureaucratic political model of each actor are as follows:

a. The Ministry of Environment and Forestry has a perspective of the status of the ab gronden as a state forest area that already has a legal basis for the designation of forest areas from the Minister of Forestry. Based on this, the Ministry of Environment and Forestry has the perspective that regions have the obligation to complete, or submit requests for completion.

b. The Local Government of Yogyakarta Special Province have the perspective that the status of the ab gronden is Sultan's land, and there is no state forest area in Yogyakarta Special Region.

c. The Head of the EFS Service's effort to resolve the ab gronden land issue by doing nothing.

Allison \& Zelikow (1999) described that the Organizational Politics Model functions in finding conflicts between actors and bargaining processes that occur as a collective decisionmaking agreement. Local governments choose the decision to "do nothing" because of problem between actors related to the perception of the status of the $a b$ gronden that requires mutual agreement. The results of the study indicate that the Organizational Politics Model cannot be done in the do nothing policy. The Organizational
Politics Model describes the bargaining process between actors. This process is not reflected in the do nothing decision making process. This model has not been able to present the decision making process in government organizations that hold legal provisions.

\section{Conclusion}

Research on occupation in the $A b$ Gronden was carried out by searching documents about the history of the $A b$ Gronden. The results of the study show the background conclusions of the EFS, Yogyakarta Special Region taking the decision of do nothing related to the problems in $A b$ Gronden because the issue of $A b$ Gronden status is not included in the policy agenda. There is no such policy agenda because the head of EFS find a dilemma and conflict in decision making related to a) differences in perceptions of the status of $A b$ Gronden between actors; b) a multi-level decision making system; and c) there is no initiation of dialogue between related actors.

This study provides an explanation of that The Organizational Politics Model has not been able to work in decision making of government organizations that are grounded in legal provisions. The do nothing decision was made because the bargaining process between the actors was not running.

\section{References}

Allison, G., \& Zelikow, P. (1999). Essence of Decision: Explaining the Cuban Missile Crisis (2nd ed.). Longman.

Awang, S. A. (2003). Politik Kehutanan Masyarakat. Center for Critical Social Studies (CCSS).

Bachrach, \& Baratz, M. (1962). Decision and Non Decision. An Analytical Framework. The American Political Science Review, 57(3 September 1962), 641-651.

Bachriadi, D., \& Wiradi, G. (2011). Enam Dekade Ketimpangan Masalah Penguasaan Tanah di Indonesia. ARC-Bina Desa dan KPA. 
Bappenas. (2009). Strategi Nasional: Akses terhadap Keadilan.

Berger, R. C., Roloff, E. M., \& Ewoldsen, D. R. (2015). Handbook Ilmu Komunikasi. Bandung: Penerbit Nusa Media.

Bernstein, S. (2014). Omissions as possibilities. Philosophical Studies, 167(1), 1-23. https:// doi.org/10.1007/s11098-013-0229-0

Boyle, C., \& Heimans, S. (2014). Take Action or Do Nothing. Equality in Education: Fairness and Inclusion, 51-57.

Cohen, K., Moffit, L. S., \& Goldin, S. (2007). Policy and Practice. The Dilemma. American Journal of Education, 113(4).

Crenson, M. (1971). The UN-Politics of Air Pollution: A Study of Non-Decision Making in the Cities. US: John Hopkins Press.

Creswell, J. (2005). Educational Research: Planning, Conducting and Evaluating Quantitative and Qualitative Research. Upper Saddle River, NJ: Pearson Education.

De Vries, M. (2010). The Importance of Neglec in Policy Making. UK: Palgrave Macmillan.

Dye, T. (1978). Understanding Public Policy. Englewood Cliffs, N.J.: Prentice Hall, Inc.

Ekawati, S., Rumboko, L., Rochmayanto, Y., Kushartati, Salaka, F., \& Muttaqin, Z. (2014). Kebijakan Land Swap Mungkinkah Dilakukan?. Pusat Penelitian dan Pengembangan Perubahan Iklim Dan Kebijakan, 8(3).

Elder, C. D., \& Cobb, R. (1971). The Politics of Agenda-Building: An Alternative Perspective for Modern Democratic Theory. The Journal of Politics, 33(4), 892-915.

Fernando, J. (2010). Eksistensi Sultan Ground dalam Hukum Tanah Nasional di Desa Srigading, Sanden Kabupaten Bantul.Jurnal Kebijakan dan Administrasi Publik, 15(2).

Flyvberg, B. (2006). Five Misunderstanding about Case Study Research. Qualitative Inquiry, 12(2), 219-245.
Forest Watch Indonesia. (2014). Potret Keadaan Hutan Indonesia Periode Tahun 2009-2013. Kartodihardjo, H. (2016). Diskursus dan Kebijakan Institusi-Politik Kawasan Hutan. menelusuri Studi Kebijakan dan Gerakan Sosial Sumberdaya Alam di Indonesia.

Kartodihardjo, H. (2017). Kepemerintahan dan Kebijakan Kehutanan: Soal Diskursus dan Reduksi Ilmu Pengetahuan. FORCI.

Kay, A. (2006). The Dynamics of Public Policy. Theory and Evidence. UK: Edward Elgar Publishing Limited.

Lukes, S. (2005). Power: A Radical View. California: McMillan/Basingstoke Palgrave.

McConnell, A., \& 't Hart, P. (2019). Inaction and public policy: Understanding why policymakers 'do nothing.' Policy Sciences, 52(4), 645-661. https://doi.org/10.1007/ s11077-019-09362-2

Moss, L. S., \& Tubbs, S. (1996). Human Communication. Prinsip-prinsip Dasar. PT Remaja Rosdakarya.

Poerwokoesoemo, S. (1985). Kasultanan Yogyakarta. Gadjah Mada University Press. Poerwonegoro, S. (1953). Djati Djawa.

Purwanto, E., \& Sulistyastuti, D. (2012). Implementasi Kebijakan: Konsep dan Aplikasinya di Indonesia. Jakarta: Gaya Media.

Ritov, I., \& Baron, J. (1990). Reluctance to vaccinate: Omission bias and ambiguity. Journal of Behavioral Decision Making, 3, 263-277.

Rose, R., \& Davies, P. (2014). Inheritance in Public Policy: Changing without Choice in Britain. UK: Yale University Press.

Rostow, E. V., \& Friedmann, W. (1972). The State and the Rule of Law in a Mixed Economy. Columbia Law Review, 72(4), 788. https:// doi.org/10.2307/1121291

Steunenberg, B. (2006). Turning Swift PolicyMaking into Deadlock and Delay: National Policy Coordination and the Transposition 
of EU Directives. European Union Politics, 7(3), 283-319. https://doi.org/10 $1177 / 1465116506066258$

Syafran. (2016). Konflik Pertanahan dalam Kebijakan Pertambangan Pasir Besi di Kabupaten Kulon Progo Daerah Istimewa
Yogyakarta. Yogyakarta: Universitas Gadjah Mada.

WALHI. (1999). Lembaga Pembebasan Tanah dalam Tinjauan Hukum dan Sosial. Prisma. Yin, R. (2009). Case Study Research. US: Sage Publications Newburry Park. 